\title{
Basin Ecosystem Management in the Upper Han River for the South to North Water Division Project, China
}

Siyue Li* and Quanfa Zhang*

Key Laboratory of Aquatic Botany and Watershed Ecology, Wuhan Botanical Garden, the Chinese Academy of Sciences, Wuhan 430074, China

\begin{abstract}
China implemented the South to North Water Division Project (SNWDP) in 2002, and the three-route (i.e., East, Middle, and West) Project is capable of transferring a total of 41.3 billion $\mathrm{m}^{3}$ of water annually from the water rich Yangtze River to the drought Northern China. The upper Han River basin is the water source area of the SNWDP's Middle Route, thus its aquatic ecosystem and water quality is of great concern. Field surveys and estimated soil erosion concerned with morphological properties from digital terrain model and land use/land cover were conducted and water quality variables were examined in April and October 2006 respectively in order to determine the major eco-environmental consequences such as land use and soil erosion, water pollution and building of hydropower dams in the basin. Hydroclimatologic data from Ankang and Danjiangkou demonstrated temperature rise of $0.29^{\circ} \mathrm{C} / 10$ a, and significantly decreases of precipitation and runoff $\left(78 \times 10^{8} \mathrm{~m}^{3} / 10 \mathrm{a}\right)$ in the recent 30 years. The upper Han River catchment with an erosion intensity of $1980-4400 \mathrm{t} / \mathrm{km}^{2} / \mathrm{yr}$, transported $3 \times 10^{8} \mathrm{t} / \mathrm{yr}$ of soils to the river, and $40 \%$ of the riparian zone in some sub catchment was cultivated though the entire basin had a vegetated coverage of $77 \%$. Moreover, chemical oxygen demand (COD) and nitrogen were the major pollutants in the upper Han River with considerably increases in the past 40 years, which would be further exaggerated by dam construction and global warming. Ultimately, corresponding strategies including proper land use, water pollution control, ecologically sustainable management for hydropower station and establishment of eco-environmental monitoring network were introduced for maintaining a scientifically sound aquatic ecosystem and satisfactory water quality in the upper Han River for the interbasin water transfer project.
\end{abstract}

Keywords: Climate change; Soil erosion; Water quality; EcoEnvironmental consequences; River basin management

\section{Introduction}

Escalating human populations and economic development have significantly contributed to environmental issues such as global warming, ozone depletion, loss of biodiversity, acid rain, vegetation destruction, soil erosion, land desertification, water quality deterioration and atmospheric pollution [1-4] Humans and natural ecosystems are competing with each other for water needs and as such multifunctional, intensive and improper freshwater usages have imbalanced a variety of water uses for drinking, industry, agriculture and recreation [5]. This further results in consequences of toxicity, eutrophication, acidification, floods and droughts [3,6] which greatly threatens human survival and sustainable economic development. Global and regional environmental projects on sustainable water uses and river managements have been carried out [7-10].

Catchment ecosystem management is primarily concerned with land management and in particular anthropogenic effects on water resources [11,12]. Inappropriate exploitation and strong economic pressures have resulted in elevating soil erosion in the southern provinces of China and stressing flood disasters in the Yangtze River $[3,13,14]$. The intended use of the upper Han River as a water source area of the Middle Route of the South to North Water Division Project (MRSNWDP), to supply water for North China, including Beijing and Tianjin City, has been delayed to 2014 (planned in 2010) due to potential ecological consequences. Water quality in the upper reaches of the Han River is of great concern due to decreasing vegetation coverage, soil erosion, natural disasters (i.e., landslide and flood) and waste discharges $[15,16]$. Past studies reported water quality [17-20], water geochemistry [21-23], water quality and land use interactions $[24,25]$ in the upper Han River basin, and indicated the River was primarily polluted by nitrogen, organic matter and several heavy metals $[19,20,26]$, and has undergone intensive anthropogenic activities particularly in the riparian corridor [25]. Local climate change, i.e., temperature rise of $0.07^{\circ} \mathrm{C} / 10 \mathrm{a}$ as high as $0.24^{\circ} \mathrm{C} / 10 \mathrm{a}$, further altered the hydrological processes and patterns of precipitation in the river basin $[27,28]$ and therefore water quality. Therefore, a framework of basin ecosystem management for the aquatic ecosystem and favorable water quality is urgent.

An extensive investigation and sampling of the upper Han River has been attempted to provide a better understanding of the anthropogenic influences on mesoscale catchments of China, and characterize water quality and major environmental concerns such as climate change, land use and soil erosion, water pollution and dam construction in the basin. Ultimately, a scientifically sound river ecosystem management, including ecological plans for land use, water pollution control, ecological management of hydropower stations and dams, and an eco-environmental monitoring network in combination with Chinese Ecosystem Research Network were introduced. The present study would help maintain an ecologically sound hydro-ecosystem and satisfactory water quality in the Han River and other catchments facing similar consequences.

*Corresponding authors: Siyue Li, Key Laboratory of Aquatic Botany and Watershed Ecology, Wuhan Botanical Garden, The Chinese Academy of Sciences, Wuhan 430074, P.R. China, Tel: +86 27 87510702; Fax: +86 27 87510251; E-mail: syli2006@163.com

Quanfa Zhang, Key Laboratory of Aquatic Botany and Watershed Ecology, Wuhan Botanical Garden, The Chinese Academy of Sciences, Wuhan 430074, P.R. China, Tel: +86 27 87510702; Fax: +86 27 87510251; E-mail: qzhang@wbgcas.cn

Received November 21, 2011; Accepted January 18, 2012; Published January 21, 2012

Citation: Li S, Zhang Q (2012) Basin Ecosystem Management in the Upper Han River for the South to North Water Division Project, China. J Environment Analytic Toxicol S3:002. doi:10.4172/2161-0525.S3-002

Copyright: (c) 2012 Li S, et al. This is an open-access article distributed unde the terms of the Creative Commons Attribution License, which permits unrestricted use, distribution, and reproduction in any medium, provided the original author and source are credited. 
Citation: Li S, Zhang Q (2012) Basin Ecosystem Management in the Upper Han River for the South to North Water Division Project, China. J Environment Analytic Toxicol S3:002. doi:10.4172/2161-0525.S3-002

Page 2 of 8

\section{Materials and Methods}

\section{The study area}

The Han River is the largest tributary in the middle stream of the Yangtze River, and originates in the Qinling-Daba Mountains and flows about $1577 \mathrm{~km}$ eastwards to the Yangtze River in Wuhan city, Hubei Province. The drainage basin covers a total area of approximately $159 \times 10^{3} \mathrm{~km}^{2}$. The upper basin $\left(31^{\circ} 20^{\prime}-34^{\circ} 10^{\prime} \mathrm{N}, 106^{\circ}-112^{\circ} \mathrm{E} ; 210-3500\right.$ $\mathrm{m}$ a.s.l; Figure 1) extends from the headwater to Danjiangkou Reservoir, extending $925 \mathrm{~km}$ in length with a drainage area of approximately $95.2 \times 10^{3} \mathrm{~km}^{2}$, and flows through Shaanxi, Gansu, Sichuan, Henan and Hubei province, which provides water for the Middle Route of South to North Water Division Project (MRSNWDP). The mountainous region accounts for $92.4 \%$ of the total drainage basin area, $5.5 \%$ for mounds and $2.1 \%$ for plains, respectively. The average runoff in the Han River is $59.1 \times 10^{9} \mathrm{~m}^{3} / \mathrm{yr}$, and the average runoff of its upper reaches is about $41.1 \times 10^{9} \mathrm{~m}^{3} / \mathrm{yr}[24]$.

In 2002, [29] China implemented the three-route (i.e. East, Middle and West) South to North Water Division Project after a 50-year feasibility study. After the completion of the project in 2050, the three routes will be capable of transferring a total of 41.3 billion $\mathrm{m}^{3}$ of water annually from the water rich Yangtze River to the drought prone North China Plain and Northwest China, with 14.8 billion $\mathrm{m}^{3}, 9.5$ billion $\mathrm{m}^{3}$ and 17 billion $\mathrm{m}^{3}$ being diverted by the East, Middle and West Routes respectively [22]. The amount of diverted water is similar to the total annual discharge of the Yellow River. MRSNWDP started on December 30, 2003 with a capacity of transferring a total of 9.5 billion $\mathrm{m}^{3}$ of water annually from Danjiangkou Reservoir on the Han River to the municipalities (Beijing and Tianjin city) [30] through canals that will be built along Funiu and Taihang Mountains. In the future, additional water will be obtained from the Three Gorges Reservoir or downstream of the dam on main channel of the Yangtze River.

\section{Data sources}

Catchments were drawn from ArcGIS 3.2 in combined with Chinese map and field survey (including land use, geology and landscape), and most of the tributaries extend more than $100 \mathrm{~km}$ with a drainage area of more than $1000 \mathrm{~km}^{2}$. Two field campaigns representing the dry season (April 2006) and rainy season (October 2006) respectively were conducted from 42 tributaries with varying landscape settings along the upper Han River (Figure 1)

Dissolved oxygen (DO), $\mathrm{pH}$, ammonia-N $\left(\mathrm{NH}_{4}^{+}-\mathrm{N}\right)$, nitrite- $\mathrm{N}$ $\left(\mathrm{NO}_{3}-\mathrm{N}\right)$ and turbidity were measured in situ, $10 \mathrm{~cm}$ below the surface and $10 \mathrm{~cm}$ above the bottom using a combination sonde (YSI 6920; YSI incorporated, Yellow Springs, Ohio, USA) calibrated prior to and after sampling to ensure accuracy. Due to the shallow, well-mixed nature of the rivers, surface and bottom data were very similar.

We therefore used surface data in this paper.

Duplicate, unfiltered water samples were collected from $10 \mathrm{~cm}$ below the surface using sample-rinsed $2500 \mathrm{ml}$ high density polyethylene bottles with teflon-lined caps and kept at ambient temperature in the dark during transport. One portion was added $\mathrm{H}_{2} \mathrm{SO}_{4}(1: 3)$ till the $\mathrm{pH} 2$ for chemical oxygen demand (COD) measures.

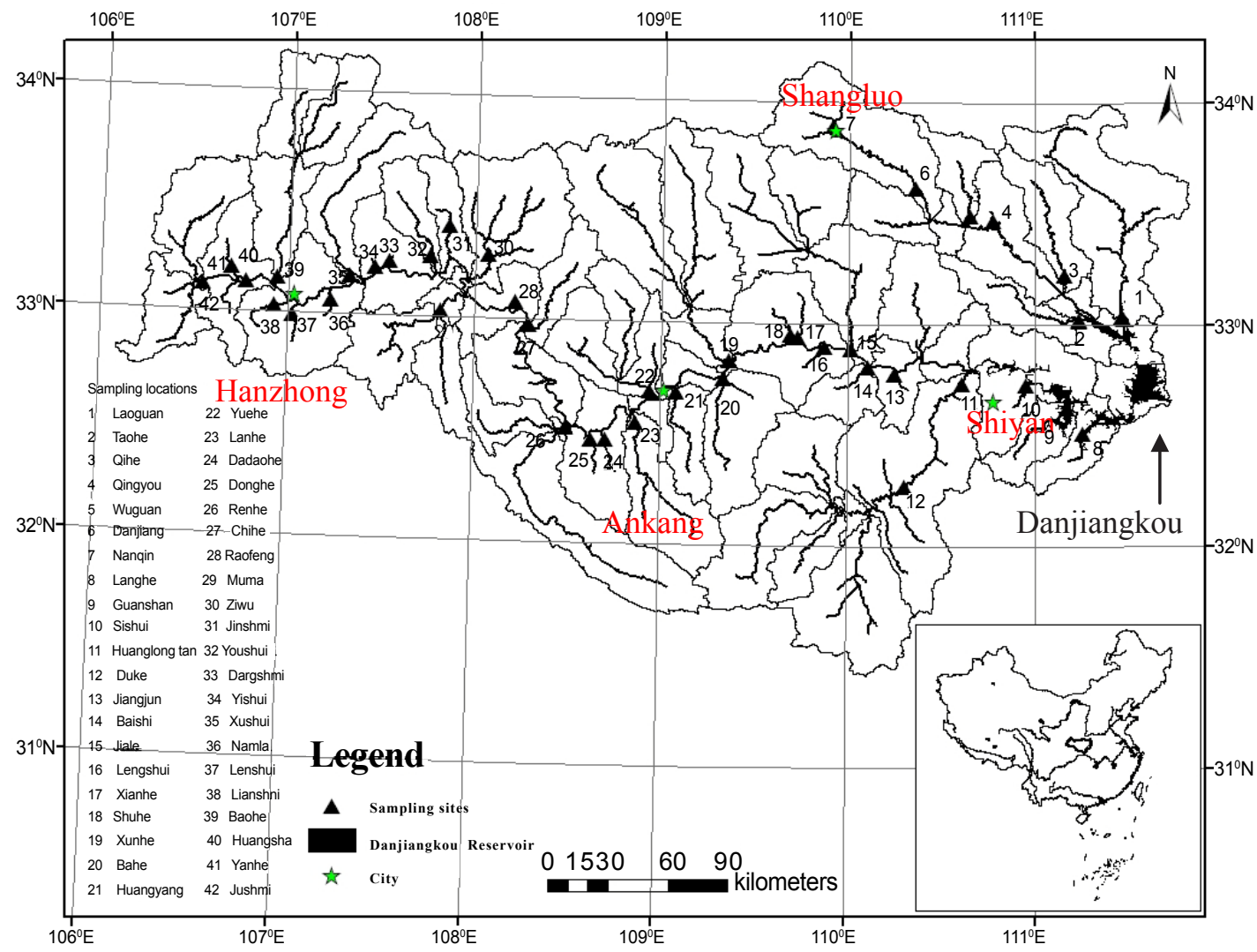

Figure 1: Sampling locations with drainages for water quality measurements along the river networks in the upper Han River basin, China. 
Citation: Li S, Zhang Q (2012) Basin Ecosystem Management in the Upper Han River for the South to North Water Division Project, China. J Environment Analytic Toxicol S3:002. doi:10.4172/2161-0525.S3-002

Morphological characteristics (watershed slope and area) were derived from a digital terrain model (DTM), and land use/land cover within the entire catchment and the $100 \mathrm{~m}$ buffer zone from landsat TM and + ETM with a hybrid of supervised and unsupervised classification algorithms. Past studies have determined land use/ land cover compositions in the basin [24,25]. Here, other landscape properties including slope area and land use/land cover distributions with various slope and estimated soil erosion using integration of land use and slope were complemented.

Annual water flows to the Danjiangkou Reservoir representing the runoff in the upper Han River were collected from 1930-2008. Air temperature and precipitation in the meteorological station of Ankang were also collected for determine climate change in the upper Han River. Then regression analysis and Kendal Tau tests were used to analyze their trends, all the processes were conducted in SPSS 15.0 with a significance level at $\mathrm{p}<0.05$.

\section{Main Human Impacts on Aquatic Ecosystem in the Upper Han River}

\section{Climate change}

We are witnessing global and local warming by anthropogenic green house gas emissions, resulting in alterations of precipitation, such as intensification of heavy rainfall but fewer days of rain. This undoubtedly changes the hydrological processes in the River. Our data in the Ankang station indicated the increase of $0.29^{\circ} \mathrm{C}$ per 10 years for temperature (Figure 2a), comparable to the past observations using one station in a county locating in the headwater of the Han River $\left(0.23^{\circ} \mathrm{C} / 10 \mathrm{a}\right)[31]$

Precipitation in the Ankang station showed insignificant variation over 1957-2010 (Figure 2b), however, significant decrease in precipitation was found for 1957-1992 $\left(\mathrm{R}^{2}=0.4, \mathrm{P}<0.05\right)$ and also did for the recent 18 years $(1993-2010)\left(R^{2}=0.39, p<0.05\right)$ (split the Figure 2
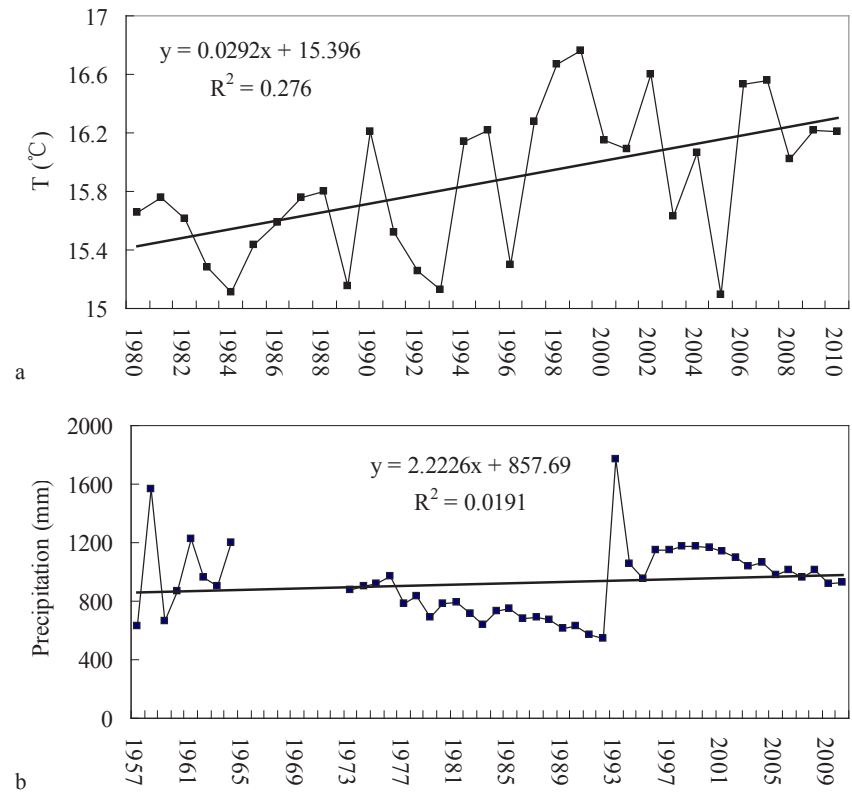

Figure 2: Temperature (1980-2010) and precipitation (1957-2010) trends in the Ankang station (data from NOAA). $\mathrm{P}<0.05$ by Kendall's tau test for temperature, and precipitation during the two periods of 1957-1992 and 19922010, respectively.
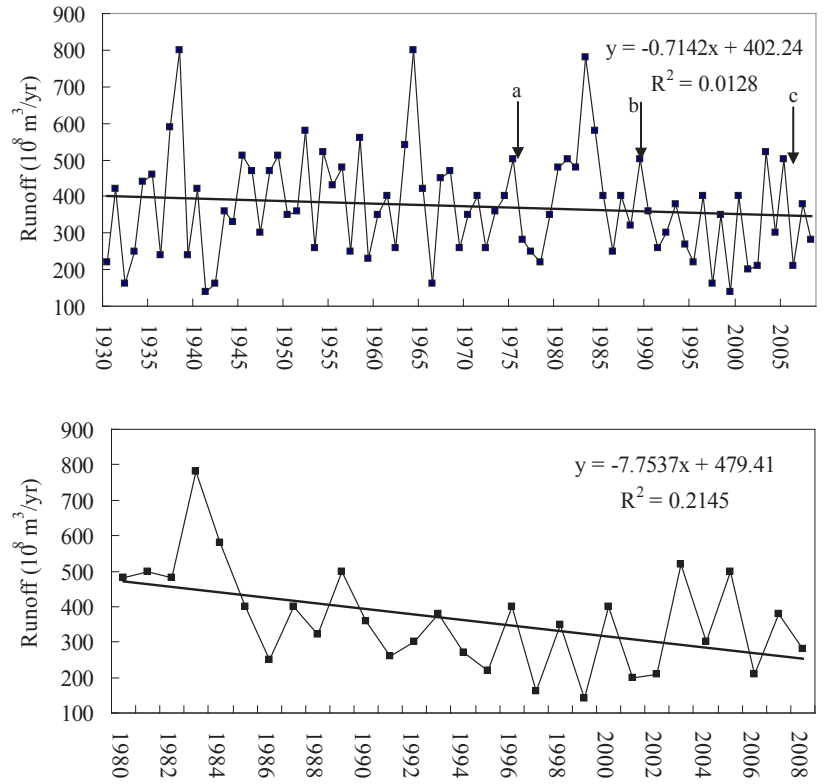

Figure 3: Runoff entering the Danjiangkou Reservoir over 1930-2008 (a-Shiquan Reservoir, b-Ankang Reservoir, c-Xihe Reservoir) (significant decrease over 1980-2008 by Kendall's tau_test) [32].

to two parts). Though water discharge is unavailable in our study, [28] analyzed the precipitation and water discharge using data (1961-2005) from several stations in the upstream of Ankang, demonstrating that both precipitation and runoff decreased obviously, and runoff could be modeled by precipitation and temperature, i.e., $\log \mathrm{Q}=1.835 \log$ Precipitation - 0.048Temperature - $2.042\left(\mathrm{R}^{2}=0.98, \mathrm{p}<0.01\right)$. There is understandably reduced runoff entering the Danjiangkou Reservoir in the recent 30 years $\left(R^{2}=0.21, p<0.05 ; 1980-2008\right)$, though water flows into the Danjiangkou Reservoir slightly decreased at $7 \times 10^{8} \mathrm{~m}^{3} / 10 \mathrm{a}$ during the period of 1930-2008 (Figure 3). Our averaged runoff of the Reservoir is around $379 \times 10^{8} \mathrm{~m}^{3} /$ year.

In addition, precipitation in the wet season (May-Oct.) was more intensified in 2000-2008 compared to that during 1956-1989 [32].

\section{Land use and soil erosion}

Unreasonable land utilization and soil erosion profoundly impact river ecosystems. The steep mountainous region in the basin easily causes soil loss, and the soil erosion area accounts for approximately $50 \%$ of the total land area in the basin (Figure 4). The headwater of the basin and high mountainous regions (the South of Qinling Mts. and the North of Daba Mts.) has an averaged soil erosion intensity of more than $2700 \mathrm{t} / \mathrm{km}^{2} / \mathrm{yr}$ (Figure 4 ). Totally, the upper basin has an average of erosion intensity of $1980-4400 \mathrm{t} / \mathrm{km}^{2} / \mathrm{yr}$, corresponding to $3 \times 10^{8} \mathrm{t} / \mathrm{yr}$ of soils to the river ecosystem. The soil erosion could be more intensified by the integration of local urbanization and more concentrated rainfall due to climate warming (Figure 2). The estimated soil erosion has an intensity up to $5000 \mathrm{t} / \mathrm{km}^{2} / \mathrm{yr}$ in the several streams (Dadao, Ren, Xun and Lan Rivers) with large spatial variability, and a rapid increase of soil erosion in the past 10 years [16]. This resulted in that upper Han River, with a silt transportation capacity accounting for some $12 \%$ of that of the Yangtze River ( 0.3 vs $2.5 \times 10^{8} \mathrm{t} / \mathrm{yr}$ for the upper Han River and Changjiang, respectively), accounts for about $5 \%$ of the total area of the Yangtze River. 
Citation: Li S, Zhang Q (2012) Basin Ecosystem Management in the Upper Han River for the South to North Water Division Project, China. J Environment Analytic Toxicol S3:002. doi:10.4172/2161-0525.S3-002

Page 4 of 8

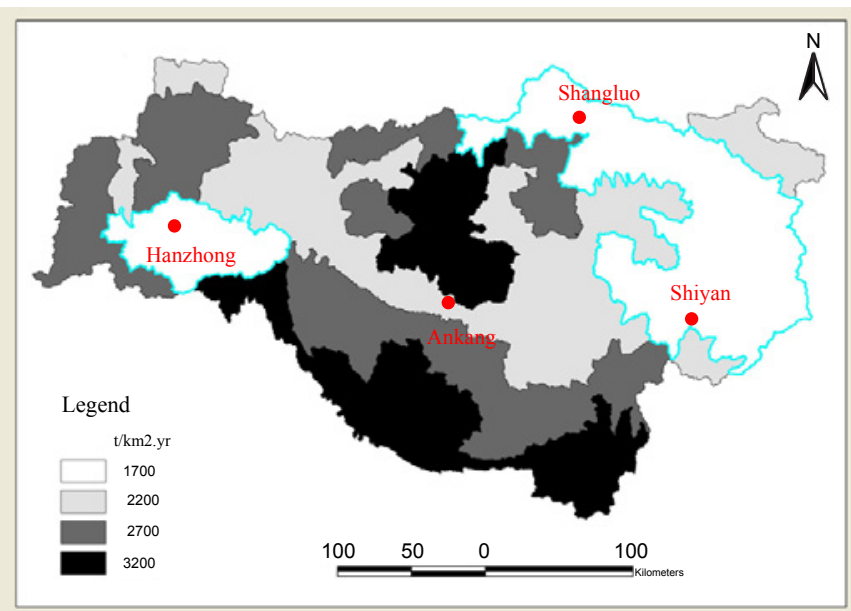

Figure 4: Estimated soil erosion in the upper Han River basin, China.

The vegetated coverage including coniferous, deciduous forest, mixed coniferous and broad-leaved forest, shrub and herb accounts for approximately $77 \%$ of the total land area in the basin [33]. The vegetated land covers $95.7 \%$ of the respective land area in the Ziwu River and 71.2\% in the Danjiangkou Reservoir [24]. Agriculture and urban respectively accounts for $14 \%$ and $0.5 \%$ of the catchment area [24,33]. Thus, the upper Han River is dominated by vegetated coverage with low anthropogenic disturbances. However, there is intense human activities within the $100 \mathrm{~m}$ riparian strip in the drainage basin, reflected by that urban and agriculture comprise $2.5 \%$ and $35.7 \%$ of the total area, and urban accounts for $5 \%$ in the Hanzhong Plain, while agriculture accounts for more than $40 \%$ in the South of the Qinling Mountain, Hanzhong Plain and Ankang Plain, respectively [25]. Another concern is agriculture in the region with a steep slope. Our results demonstrate $1500.8 \mathrm{~km}^{2}$ of cultivated land in the area with slope greater than $25^{\circ}$ (Table 1), which urgently needed to be reforested. Overall, anthropogenic activities are concentrating along the river networks, and we can hypothesize the increasing soil erosion in the basin due to the urbanization, particularly land cultivation in catchments with steep slopes, and the increased frequency of storms by climatic change.

Nevertheless, past land use over 1980-2000 demonstrated little alterations of land coverage (Table 2), we must note the decline of natural forest and then massively reforestation due to China's "Grain-to Green" project since 1990s, which undoubtedly changes the hydrological processes and enhances soil erosion.

\section{Water pollution due to industrial and domestic discharges}

Field surveys indicated that industrial wastewater from chemical plants and domestic wastes (household refuse, piggeries, etc) discharged directly into rivers such as Xian River, Bai River, Xushui River, Baishi River and the rivers near Shiquan County. Our monitoring data demonstrated that $\mathrm{pH}$ and $\mathrm{DO}$ tended to have higher values in April (low flow period, 7.2-9.1 for $\mathrm{pH}$ and 9-17 for DO) compared to October (water-rich period, 6.7-8.7 for $\mathrm{pH}$ and 3.8-13.5 for DO). COD and nitrogen showed higher concentrations in October 2006, and turbidity had remarkable variability with much higher values in several rivers (Figure 5). Compared to the World Health Organization (2006) [34] and Chinese State Standards [35] (CSS) (2006) for drinking water, concentrations of turbidity, COD and nitrogen exceed the permissible levels.
Water quality of upper reaches of the Han River has been deteriorating due to industrial and domestic wastes since 1970s (Figure 6). Nitrogen concentration increased swiftly during the period of 1990s-2006, i.e., $\mathrm{NH}_{4}-\mathrm{N}$ in 2006 was 5 -fold the concentration in 1997 (Table 3). This excess of nutrients caused phytoplankton blooming in the rainy season e.g., August 2011 in the Danjiangkou Reservoir (http://219.140.196.67:8080/hjsw/Article/ShowArticle. asp?ArticleID=1972; Accessed in Oct. 2011). In terms of the Han River's main stream, total hardness, nitrogen, $\mathrm{Cl}, \mathrm{SO}_{4}$ and $\mathrm{COD}$ increased significantly over 1970s-2010s in its section of Ankang $\left(\mathrm{R}^{2}>0.8, \mathrm{p}<0.01\right.$; Figure 6). Also, water quality changed from level in 1994 to level or in 2000 according to the Surface Water Environment Quality Standard in China. Moreover, rivers (i.e., Shending, Majia, Maota River) through Shiyan city, are seriously polluted with water of level V, and directly flow into the Danjiangkou Reservoir (Table 4). Thus, the water will
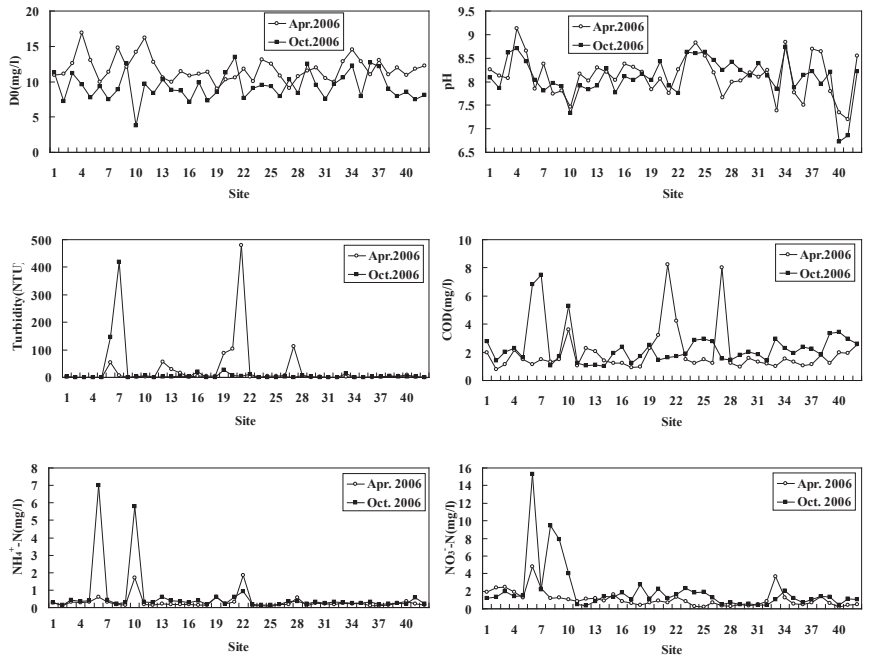

Figure 5: Water quality variables in the upper Han River basin, China
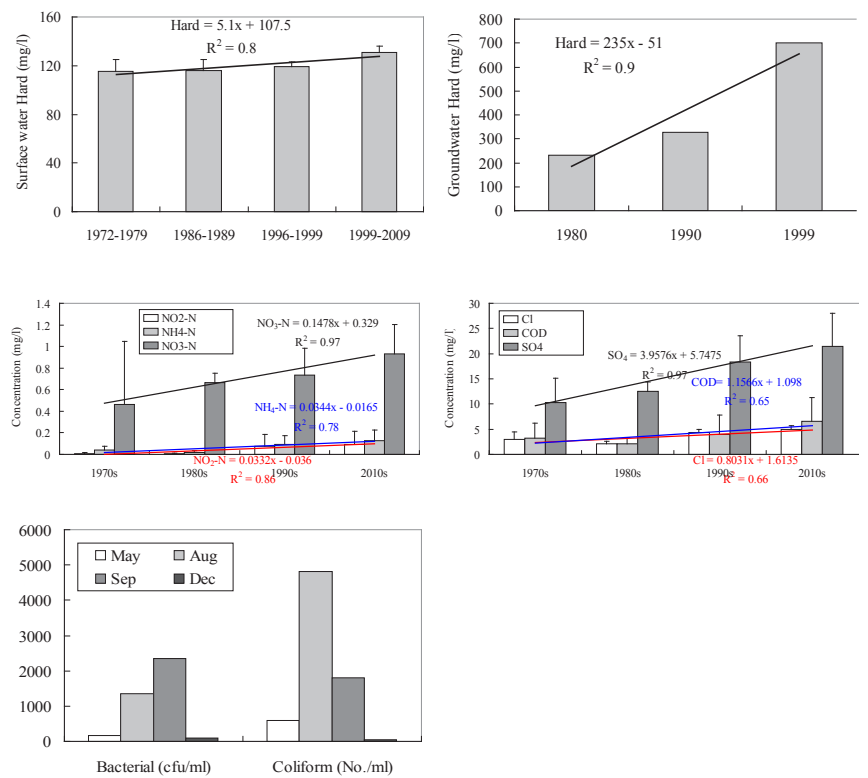

Figure 6: Long-term trends of water quality in the main stream of Han River in the Ankang, Shaanxi province [48]. 
Citation: Li S, Zhang Q (2012) Basin Ecosystem Management in the Upper Han River for the South to North Water Division Project, China. J Environment Analytic Toxicol S3:002. doi:10.4172/2161-0525.S3-002

Page 5 of 8

\begin{tabular}{|c|c|c|c|c|c|c|c|c|c|c|c|}
\hline $0^{\circ}-8^{\circ}$ & & & $8^{\circ}-15^{\circ}$ & & & $15^{\circ}-25^{\circ}$ & & & $>25^{\circ}$ & & \\
\hline $\begin{array}{l}\text { Vegetation } \\
(\%)\end{array}$ & $\begin{array}{l}\text { Agriculture } \\
(\%)\end{array}$ & $\begin{array}{l}\text { Area } \\
\left(\mathrm{km}^{2}\right)\end{array}$ & $\begin{array}{l}\text { Vegetation } \\
(\% 0)\end{array}$ & $\begin{array}{l}\text { Agriculture } \\
(\%)\end{array}$ & $\begin{array}{l}\text { Area } \\
\left(\mathrm{km}^{2}\right)\end{array}$ & $\begin{array}{l}\text { Vegetation } \\
(\%)\end{array}$ & $\begin{array}{l}\text { Agriculture } \\
(\%)\end{array}$ & $\begin{array}{l}\text { Area } \\
\left(\mathrm{km}^{2}\right)\end{array}$ & $\begin{array}{l}\text { Vegetation } \\
(\%)\end{array}$ & $\begin{array}{l}\text { Agriculture } \\
(\%)\end{array}$ & $\begin{array}{l}\text { Area } \\
\left(\mathrm{km}^{2}\right)\end{array}$ \\
\hline 52.28 & 31.75 & 16664.9 & 77.92 & 14.35 & 19510.11 & 85.25 & 9.88 & 35759.09 & 89.87 & 6.63 & 22636.91 \\
\hline
\end{tabular}

Table 1. Basin physical characteristics including slope, area and land use relating to slope in the upper Han River basin, China.

\begin{tabular}{lllll}
\hline & 1980 & 1995 & 2000 \\
Cropland & 16.88 & 16.65 & 4.14 \\
Forest & 49.16 & 49.58 & 39.23 \\
Grass & 33.11 & 32.95 & 32.88 \\
Waters & 0.75 & 0.71 & 0.63 \\
Urbans & 0.1 & 0.1 & 0.12 \\
Unoccupied & 0 & 0.01 & 0.01 \\
\hline
\end{tabular}

Data from Zhao et al (2009)

Table 2: Land use composition (\%) over 1980-2000.

\begin{tabular}{|c|c|c|c|c|}
\hline & 1990S & 1997 & Oct-2006 & Apr -2006 \\
\hline $\mathrm{NH}_{4}-\mathrm{N}$ & 0.1 & 0.09 & $0.6 \pm 1.3$ & $0.3 \pm 0.36$ \\
\hline $\mathrm{NO}_{3}-\mathrm{N}$ & & 1.04 & $2 \pm 2.7$ & $1.1 \pm 0.9$ \\
\hline Sources & Chen et al., 2000 & Liu et al., 2003 & Our study & \\
\hline
\end{tabular}

Table 3: Nitrogen variations during the period of 1990 s to 2006.

\begin{tabular}{|c|c|c|c|c|}
\hline River & Site & Environment function & Water quality & Source of pollutants \\
\hline Han River & Yangwei & Industry, agriculture and fishery & $\beta$ & \\
\hline Han River & Yangxi & Drinking and fishery & $\alpha$ & Yun County, Liupo Town \\
\hline Han River & San'guandian Town & Industry, agriculture and landscape & $\beta$ & Danjiangkou City, San'guandian Town \\
\hline Tian River & Tigerhole & Industry and agriculture & $\beta$ & Yunxi County, Guanyin and Jianchi Town \\
\hline Du River & Shagou (Peiwan-Yeda) & Industry, agriculture and fishery & $\beta$ & Zhushan County \\
\hline Du River & Huanglong Beach Reservoir & Drinking & $\alpha$ & \\
\hline Du River & Huanglong-Fang Beach & Industry, agriculture and fishery & $\beta$ & \\
\hline Shengding River & Bamudi & Agriculture and landscape & $\delta$ & Shiyan City \\
\hline Sishui River & Xujiapen, Bailangtang & Agriculture and landscape & $\chi$ & Shiyan City \\
\hline Guanshan River & Baimiao & Agriculture and landscape & $\chi$ & Liuliping Town \\
\hline Jian River & Shijiazhuan Bridge & Agriculture and landscape & $\chi$ & Wudang Town \\
\hline Lang River & Daiwan Bridge & Agriculture and landscape & $\chi$ & Lang River Town \\
\hline Malang River & Liulixia & Industry and agriculture & $\beta$ & Fang County, Qingfeng Town \\
\hline Zhuxi River & Yanba & Industry, agriculture and entertainment & $\chi$ & Zhixi County, Zhongfeng Town \\
\hline
\end{tabular}

* China State EPA, 2002

Table 4. Water environment function and control sections in of the upper Han River, China (Liu et al., 2000).

not be suitable for MRSNWDP without effective approaches for water contamination control.

Fortunately, the Chinese government has planned to reduce wastewater discharges in the Han River basin due to the implementation of the interbasin water transfer project. For instance, industrial influents have largely been curved and thus $\mathrm{COD}$ and $\mathrm{NH}_{4}-\mathrm{N}$ discharges from industry decreased significantly in the Hubei province $\left(\mathrm{R}^{2}=0.7, \mathrm{p}<0.01\right.$; Figure 7). However, chemical pollutants from domestics in the both Hubei and Shaanxi provinces slightly increased or kept constant with large contributions by domestics for $\mathrm{COD}$ and $\mathrm{NH}_{4}-\mathrm{N}$ (Figure 7). Thus, non-point sources (NPS) including agricultural nitrogen are the main pollutants in the upper Han River, as reflected by the higher loads of nitrogen in the rainy season (Oct. 2006; Figure 5) and bacterial in the Han River of Ankang (Aug.-Sep.; Figure 6). Generally, we are concerning that water problems will not be alleviated because of land degradation, household refuses (Figure 7), intensified soil erosion (Figure 4), poverty and emigration, and dam-induced land submergence (Table 5).

\section{The building of hydropower dams}

We are confident that dams will continue to be one of the most effective ways to deal with issues of water and energy scarcity and flood disasters, though the World Commission Dams generally claims their negative performances [36]. The local government is devoted to the development and utilization of water energy in the Han River. There are seven cascade reservoirs with one dam per $50 \mathrm{~km}$ in the main channel within the boundaries of Shaanxi province with a hydropower capacity of $68 \times 10^{8} \mathrm{Kw} \cdot \mathrm{h} / \mathrm{yr}$ (gross capacity of $2080 \times 10^{6}$ kilowatts) (Table 5). Also, cascade reservoirs in the tributaries within the boundaries of Hubei province have an installed gross capacity of $2.044 \times 10^{6}$ kilowatts (Table 5; $[37,38]$ ). However, the influences of hydraulic engineering on aquatic ecosystem and the structural-functional interactions of the ecosystem are unavailable.

Nonetheless, it is undoubted that the dam's impacts that destroy the integrity, self-maintenance, self-regulation and self-organization of aquatic ecosystems due to hydropower stations result in various ecoenvironmental consequences such as the alteration of hydrological regime, submergence of land and emigration of the local residents. 
Citation: Li S, Zhang Q (2012) Basin Ecosystem Management in the Upper Han River for the South to North Water Division Project, China. J Environment Analytic Toxicol S3:002. doi:10.4172/2161-0525.S3-002

Page 6 of 8

(a)

\begin{tabular}{|c|c|c|c|c|c|c|c|c|}
\hline Reservoir & Built year & water level & Drainage area & Storage & Active storage & hydropower & Installed capacity & Distance from Danjiangkou, $\mathrm{km}$ \\
\hline & & $\mathrm{m}$ & $\mathrm{km}^{2}$ & $10^{8} \mathrm{~m}^{3}$ & $10^{8} \mathrm{~m}^{3}$ & $10^{8} \mathrm{kwh} / \mathrm{yr}$ & $10^{6} \mathrm{kw}$ & \\
\hline Huangjin Gorge & & 450 & 17950 & 1.9 & & 4.6 & 100 & \\
\hline Shiquan & 1975 & 410 & 23400 & 4.7 & 2.22 & 6.34 & 225 & \\
\hline Xi River & 2006 & 362 & & 2.3 & & 4.9 & 180 & \\
\hline Ankang & 1990 & 330 & & 32 & & 28.6 & 800 & 265 \\
\hline Xunyang & 2010 & 240 & 42400 & 3.9 & & 8 & 320 & 200 \\
\hline Shu River & 2010 & 217 & & 1.8 & & 9.5 & 270 & 145 \\
\hline Bai River & & 194 & & 1.3 & 0.2 & 5.5 & 180 & 107 \\
\hline Danjiangkou & 1968 & 157 & 95200 & 209 & 201 & 38.3 & 247 & \\
\hline
\end{tabular}

(b) (Wang, 2002)

\begin{tabular}{|c|c|}
\hline Main tributary & Hydropower station \\
\hline \multicolumn{2}{|l|}{ Shaanxi } \\
\hline Bao River & Lujiaba, Jiepaiguan, Madao, Qingqia \\
\hline Xun River & Baojiaya, Caiping, Shagoukou, Jijia \\
\hline Ren River & Gaowang, Zhaojiaping, Ba Moutain, \\
\hline Lang River & Dishuiyan, Huangjiaya, Linhekou, $\mathrm{H}$ \\
\hline \multicolumn{2}{|l|}{ Hubei } \\
\hline Du River & Eping, Zhoujiawang, Longbeiwan, S \\
\hline \multicolumn{2}{|c|}{$\begin{array}{l}\text { Arguably, the most predictable effects of the natural hydrological } \\
\text { regime's alteration will be to disturb the river's original habitat } \\
\text { characteristics, i.e., the composition, structure and functioning } \\
\text { of aquatic ecosystem and riparian ecosystem [7,9]. For example, } \\
\text { hydropower station decreased the fish species from } 39 \text { in } 1987 \text { [39] } \\
\text { to } 21 \text { in } 1999 \text { [40] in Xiangxi River (a tributary of the Yangtze River). } \\
\text { Another important concern is the newly riparian ecotone may be } \\
\text { cultivated by relocating people up-hills, causing another source } \\
\text { (agricultural non-point source pollution) of pollutants to the river. }\end{array}$} \\
\hline
\end{tabular}

Based on the field survey, the aquatic ecosystem of the upper Han River has been increasingly affected by varying dam operations (Table 5), and some ecological functions have decreased or vanished due to little water downstream of dams in many tributaries particularly in summer (June 2005)

\section{Ecosystem management of the upper Han River}

The greatest challenge of river management is to balance water resource consumption and maintain the integrity of the river ecosystem. River ecological water requirements and human influences on water resource need to be balanced for water resource sustainability [9]. As the water source are for North China, water quantity and water quality are of equal importance for maintaining a sound hydro-ecosystem in the Han River. Our ultimate goal is to develop strategies for managing an ecologically sound aquatic ecosystem and water quality.

\section{Ecological plan for land use in the upper Han River}

Revegetation is critical for water conservation in a basin as vegetation coverage retains rainwater in the rainy season, thereby decreases flood intensity, and supplies water in dry season to the supplement of river flow. Past studies have stressed the relationships between the recent rapid loss of vegetation and the reduced capacity of water retention, increased soil erosion and more destructive floods in the river (e.g., $[1,3]$. However, inappropriate exploitation and strong economic pressures have resulted in decreasing vegetation coverage, and consequently decreases the capacity of water retention in the basin

[13]. Land use in the upper Han River has been determined with the help of geographic information system (GIS) and remote sensing (RS). An established mathematical model of associations between land use and river health $[24,25]$ can be used for proposing the most suitable pattern of land use. We should synthetically plan the residential district, agricultural region, industrial district and vegetated area.

There is relatively high vegetation coverage (around 77\%) in the upper Han River drainage basin [24], however, riparian land and riverbed/flood plain has been cultivated by local people particularly in the Hanzhong and Ankang Plains [25]. Degradation of the riparian zone diminishes its capacity of retaining and reducing sediments and particulate phosphorus and nitrogen by various processes of plant uptaking, microbial immobilization and soil storage [8,41], and therefore contributes to stream water pollution. Establishment of a 5-50 m-width buffer zone along river networks may be viewed as one of the most important restoration measures.

\section{Water pollution control in the upper Han River}

Researchers have developed many models integrating GIS and spatial (digital elevation model, soil and land use) [42] databases and simulated the distributed physical process of water pollution $[43,44]$, sediments and N and P. Recent efforts have been done on the integration of the physical process model and GIS to predict potential soil losses in watersheds $[1,45]$. Land use change resulting from the introduction of the large reservoir in the Han River exposes minerals to environment, and may accelerate soil erosion and increase sediments.

Presumably, reforestation could reduce soil erosion, especially in the degraded areas. Buffer strips and wet detention ponds are constructed to remove $80 \%-90 \%$ of sediment and $90 \%$ of nitrogen to rivers [41] In addition, we can examine the relationships between pollution loads and water quality with the help of Total Maximum Daily Load (TMDL) [6]. The correlation of pollutant concentration and nutrient level will be modeled on the basis of the comprehensive analysis of point pollutants source, NPS and soil loss in the basin, then its TMDL will be proposed. 


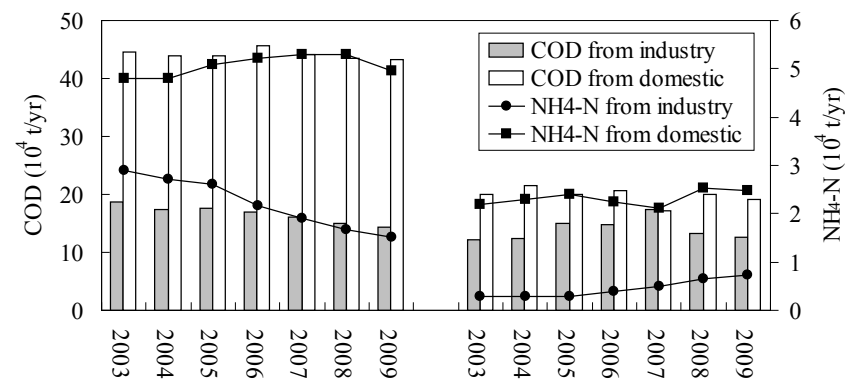

Figure 7: $\mathrm{COD}$ and $\mathrm{NH} 4-\mathrm{N}$ discharges by industrial and domestic contributions from Hubei and Shaanxi provinces (data sourced from National Bureau of Statistics of China; http://www.stats.gov.cn/).

At last, the discharges of pollutants everyday will be put forward to maintain a healthy aquatic ecosystem. Our results and historical data indicated water quality degraded in the rainy season (Figure 5and 6) contributable to NPS by runoff $[19,20]$. Field surveys found that many chemical plants in the upper Han River had no wastewater treatment facilities and their wastewater discharged directly, as reflected by the sampling sites with much higher concentrations of nitrogen located in the Danjiangkou Reservoir catchment where there is a large population center of Shiyan city (Figure 1 and 5). Ultimately, the integration of reforestation for soil erosion, water treatment for industrial sewages, wet detention ponds for urban runoff and riparian construction in agricultural areas are required

\section{The ecological management for hydropower reservoirs}

Dam operations, together with nonpoint source pollution and invasive species have greatly imperiled aquatic ecosystems $[9,46]$. Past study demonstrated that nutrients were enough to support the eutrophication in the Han River [20], thus hydrological processes is the key component controlling the eutrophication in the river, which may be regulated by dam operations. The hydrological alterations in rivers downstream of dams are controlled by the release from hydropower station and these regulated rivers' flow regime is associated to water exchange and the production-destruction processes in waters. We must establish release patterns and volumes relating to the associations between organic pollution and self-purification in order to ensure water quality conformity. It is notable that there exists the required release into downstream for self-purification of pollutants from ecosystem and anthropogenic inputs [7], and this release can balance the productiondestruction processes in rivers.

Generally, the increase of releases improves self-purification and water quality and additional increasing release have little influences on water pollutants [7]. In order to provide utmost benefits of hydropower station, the extremal release (ecological release), reflecting ecological water needs, must be determined based on several years of natural hydrological data. Further, the increasing anthropogenic contributions should be balanced by increasing water releases.

However, dams cause the breaks of geographical rivers and river flow processes, and change the transportation flux, composition and spatio-temporal distributions of matters and aquatic biogeochemical processes. The varied nutrient species, composition, and their stoichiometry by dam would lead to aquatic evolution especially the phytoplankton alternation [47]. Cascade reservoirs in the upper Han River are of great concern due to their complicated accumulative effects on river flow and biogenic elements. Unfortunately, these critical consequences may not be solved in the future.

\section{Establishment of eco-environmental monitoring network}

Long-term ecosystem research and monitoring networks are effective for describing the evolution of ecosystem. Currently, China has the Chinese Ecosystem Research Network (CERN) with 36 stations nationwide to demonstrate and study the typical ecosystems in China such as farmland, forest, lawn, desert, marsh, lake and ocean ecosystem (http://www.cern.ac.cn).

The MRSNWDP will have profoundly impacts on water receiving and supply areas, thus long-term and systematic monitoring is of necessity. A few new stations in the water supplying areas to monitor the environmental implications of the project should be launched. However, CERN only has two stations for freshwater lake ecosystems (i.e., East Lake and Taihu Ecosystem Monitoring Station). A river basin management program should be developed and implemented to monitor land use/land cover change particularly the urbanization, composition and structure and function of ecosystems, water quality and river flow regime in the Han River associated with dam operations serving for this large water transfer project. We can establish an ecosystem research station in the basin, i.e., Danjiangkou Reservoir or the typical stream such as Jinshui River in the upper section and Du River near the Danjiangkou Reservoir.

\section{Perspectives}

Land use change, particularly urban growth and other anthropogenic contributions, have had significant influences on water quality of the upper Han River as reflected by elevated nitrogen contributing to algae blooms during the spring in the past two decades, i.e., 1992, 1998, 2000, 2003 and 2008, and this water pollution would be enhanced by global warming and soil erosion. How to maintain an ecologically sound aquatic ecosystem is critical for China's interbasin water transfer project. Unfortunately, we do not know much about the composition and structure of the ecosystem of the Han River, particularly the riparian corridor. There are even fewer studies on hydroecosystem functions and how they might respond to the varying hydrologic regime in the regulated rivers associated with dam operations. With such limited knowledge, the present work has determined the major eco-environmental consequences and introduced a river basin ecosystem management plan, including the ecological management for hydropower dams, land use management, water pollution control and establishment of eco-environmental monitoring network in the upper Han River. Further study should focus on applications and interpretations of data and the development of integrated river basin management for water conservation for the MRSNWDP based on the characterization of the composition, structure and functioning of aquatic ecosystem in the Han River.

\section{Acknowledgements}

The research is funded by the National Natural Science Foundation of China (No. 31100347, and No. 31130010), the "Hundred-talent Project" of the Chinese Academy of Sciences (O629221C01), and Dr Li S.Y'S the Youth Innovation Foundation of the Chinese Academy of Sciences, China.

\section{References}

1. Mellerowicz KT, Rees HW, Chow TL, Ghanem I (1994) Soil conservation planning at the watershed level using the universal soil loss equation with GIS and microcomputer technologies: A case study. J Soil Water Cons 49: 194-200.

2. Chen X, Zong Y, Zhang E, Xu J, Li S (2001) Human impacts on the Changjiang (Yangtze) River basin, China, with special reference to the impacts on the dry season water discharges into the sea. Geomorphology 41: 111-123. 
Citation: Li S, Zhang Q (2012) Basin Ecosystem Management in the Upper Han River for the South to North Water Division Project, China. J Environment Analytic Toxicol S3:002. doi:10.4172/2161-0525.S3-002

Page 8 of 8

3. Yin $\mathrm{H}$, Li C (2001) Human impact on floods and flood disasters on the Yangtze River. Geomorphology 41: 105-109.

4. Feng $\mathrm{H}$, Han $\mathrm{X}$, Zhang $\mathrm{W}$, Yu L (2004) A preliminary study of heavy metal contamination in Yangtze River intertidal zone due to urbanization. Mar Pollut Bull 49: 910-915.

5. Schneiders A, Verheyen RF (1998) A concept of integrated water managemen illustrated for Flanders (Belgium). Ecosystem Health 4: 256-263.

6. Schreiber JD, Rebich RA, Cooper CM (2001) Dynamics of diffuse pollution from US southern watersheds. Water Research 35: 2534-2542.

7. Timchenko V, Timchenko O, Gore J (2000) A model for ecosystem state and water quality management in the Dnieper River delta. Ecological Engineering 16: $119-125$

8. Kuusemets $\mathrm{V}$, Mander $\mathrm{U}$ (2002) Nutrient flows and management of a smal watershed. Landscape Ecology 17: 59-68.

9. Richter BD, Mathews R, Harrison DL, Wigington R (2003) Ecologically sustainable water management: managing river flows for ecological integrity. Ecological Applications 13: 206-224

10. Kojiri T (2008) Importance and necessity of integrated river basin management Physics and Chemistry of the Earth 33: 278-283.

11. Dorn JL, Ranjithan SR (2003) Evolutionary multiobjective optimization in watershed water quality management. In: Fonseca, C M et al. (Eds.) EMO2003, LNCS2632, pp 692-706.

12. Kalnay E, Cai M (2003) Impacts of urbanization and land use change on climate. Nature 423: 528-530.

13. Guo Z, Gan Y (2002) Ecosystem function for water retention and forest ecosystem conservation in a watershed of the Yangtze River. Biodiversity and Conservation 11: 599-614.

14. Qiu J (2010) China drought highlights future climate threats. Nature 465: 142 143

15. Li S, Zhang Q (2008b) Revegetation for the environmental improvement in the Danjiangkou Reservoir-Water supplying area of the Middle Route of the South to North Water Transfer project. China Rural Water and Hydropower 1-4.

16. Li S, Liu W, Gu S, Han H, Zhang Q (2009d) Eco-environmental crisis and countermeasures of the upper Han River basin (water source area of the Middle Route of the South to North Water Transfer Project ), China. Resources and Environment in the Yangtze Basin 18: 275-280.

17. Chen J, Gao X, He D, Xia X (2000) Nitrogen contamination in the Yangtze River system, China. Journal of Hazardous Materials 73: 107-113.

18. Li S, Xu Z, Cheng X, Zhang Q (2008b) Dissolved trace elements and heavy metals in the Danjiangkou Reservoir, China. Environ Geol 55: 977-983.

19. Li S, Cheng X, Xu Z, Han H, Zhang Q (2009a) Spatial and temporal patterns of the water quality in the Danjiangkou Reservoir, China. Hydrolog Sci J 54: 124-134.

20. Li S, Liu W, Gu S, Cheng X, Xu Z, et al. (2009c) Spatio-temporal dynamics of nutrients in the upper Han River basin, China. J Hazard Mater 162: 1340-1346.

21. Li S, Zhang Q (2008a) Geochemistry of the upper Han River basin, China, 1 : Spatial distribution of major ion compositions and their controlling factors. Appl Geoche 23: 3535-3544

22. Li S, Zhang Q (2009) Geochemistry of the upper Han River basin, China 2 Seasonal variations in major ion compositions and contribution of precipitation chemistry to the dissolved load. J Hazard Mater 170: 605-611.

23. Li S, Xu Z, Wang H, Wang J, Zhang Q (2009e) Geochemistry of the upper Han River basin, China 3: Anthropogenic inputs and chemical weathering to the dissolved load. Chem Geol 264: 89-95.

24. Li S, Gu S, Liu W, Han H, Zhang Q (2008a) Water quality in relation to the land use and land cover in the Upper Han River basin, China. Catena 75: 216-222.

25. Li S, Gu S, Tan X, Zhang Q (2009b) Water quality in the upper Han River basin China: the impacts of land use/land cover in riparian buffer zone. J Hazard Mater 165: 317-324.

26. Li S, Xu Z, Cheng X, Zhang Q (2008b) Dissolved trace elements and heavy metals in the Danjiangkou Reservoir, China. Environ Geol 55: 977-983.
27. Karl TR, Trenberth KE (2003) Modern global climate change. Science 302 1719-1723.

28. Cai X, Sun X, Qiao Q, Jiang C, Mao M (2008) Effects of climate change on runoff volume in the upper reaches of the Hanjiang River. Advance in climate change research 4: 220-224

29. China State EPA (2002) Environmental quality standards for surface water GB 3838-3888.

30. Zhao G, Zhao X, Wang D (2003) The problem and strategy of ecology protection and reconstruction of Danjiangkou Reservoir' water source area in Shaanxi province. Soil and Water Conservation of China 11-12 (in Chinese with English abstract).

31. Bu H, Dang H, Zhang Q (2009) Climate change in the Jinshui River basin of the Upper Han River in recent 50 years and its impacts on ecological environment. Resources and environment in the Yangtze Basin 18: 459-465

32. Zhao H, Chen N, Jiang Y, Lu F, Zhang S (2009) Temporal-spatial evolution of water resources in the upstream of the Hanjiang basin and cause analysis. South-to-North Water Transfer and Water Science \& Technology 7: 90-94

33. Gu S, Cheng X, Shen Z, Zhang Q (2007) Watershed Characteristics of the Upper Reaches of the Hanjiang River Basin. Resour. Environ Yangtze Basin 16: 38-44.

34. WHO (2006) Guidelines for Drinking-Water Quality, third ed, vol 1Recommendations. Word Health Organization, Geneva.

35. Chinese Ministry of Health, PR China (2006) Chinese State Standards (CSS) for Drinking Water Quality, GB5749-2006

36. Zhang J (2001) Comments on WCD's final report in the documents offers to ICOLD members countries the publications of their national conclusions and comments report.

37. Cao S, Tian F (1999) Water power resources development in upper stream of the Hanjiang River. Journal of Shaanxi Waterpower 15:29-33.

38. Wang $H$ (2002) Models for speeding up development of hydropower on the upper Hanjiang River. Northwest hydropower 1-4.

39. He C (1990) The fish resource investigation of Xiangxi River. Hubei fishery 84 85 (in Chinese). (read on Jan. 2010)

40. Xiang H (1999) Xiangxi River's fishery resources and the initial research of Three Gorge' effects. Bulletin of Biology 34:42.

41. Liu D, Wang H, J iang Y, Wan D, Dai J (2000) Water pollution control schemes for upstream of Hanjiang River. Earth Science-Journal of China University of Geosciences 25:487-491 (in Chinese with English abstract)

42. Peterjohn WT, Correll DL (1984) Nutrient dynamics in an agricultural watershed: observations on the role of a riparian forest. Ecology 65: 1466-1475.

43. Young R, Onstad CA, Bosch DD, Anderson WP (1987) AGNPS: Agricultura Non-Point Source Pollution Model: a watershed analysis tool,USDA-Agricultura Research Service. ConservationResearch Report 35 US Department of Agriculture, Washington, DC

44. Bhuyan SJ, Koelliker JK, Marzen LJ, Harrington JA (2003) An integrated approach for water quality assessment of a Kansas watershed. Environ Modelling Software 18: 473-484.

45. Fraser RH, Warren MV, Barten PK (1996) Comparative evaluation of land cove data sources for erosion prediction. Water Resources Bulletin 31: 991-1000.

46. Pringle CM, Freeman MC, Freeman BJ (2000) Regional effects of hydrologic alterations on riverine macrobiota in the New World: tropical-temperate comparisons. BioScience 50: 807-823.

47. Rosenberg DM, Mccully P, Pringle CM (2000) Global scale environmental effects of hydrological alterations introduction. BioScience 50:746-751.

48. Wang Q (2010) Water resources investigation report of Ankang in Hanjiang, Anhui agri, Sci bull 16, 28-30 (in Chinese with English abstract).

This article was originally published in a special issue, Environmental Pollutants handled by Editor(s). Dr. Ben-Zhan (Benny) Zhu, China; Dr. Aijie Wang, China 